Journal of Economics and Behavioral Studies

Vol. 5, No. 11, pp. 762-776, Nov 2013 (ISSN: 2220-6140)

\title{
Can Owner-Manager Characteristics Signal Small Business Loan Default Propensity?
}

\author{
Eresia-Eke, CE \\ University of Pretoria, South Africa \\ chuks.eresia-eke@up.ac.za
}

\begin{abstract}
The potential of small businesses is inhibited by a cocktail of problems of which inaccessibility to finance is pre-eminent. This problem is linked to the lenders' risk estimation, often based on financial indicators which small businesses are not adept at using to signal their performance ability. This situation, especially in South Africa, with a history of a people who were previously disadvantaged does not aid the development of small businesses that may well be the antidote for overcoming the strain of poverty and unemployment in the country. This study stems from the human capital theory and investigated possible relationships between owner-manager characteristics and loan default propensity. The aim being to unveil non-financial variables, associated with the owner-manager which could be relied upon by lenders' to estimate the loan default propensity of the small business borrower. Primary data collected in South Africa were empirically analysed for possible associations between owner-manager characteristics and loan default propensity. Results revealed business size-dependent differences in the association between certain ownermanager characteristics and business loan default propensity. The implication of this for all stakeholders is that considerations for small business lending should be sensitive to business size.
\end{abstract}

Keywords: Small, Micro and Medium Enterprises (SMMEs); Entrepreneurship; Small Business Finance; OwnerManager; Loan Default Propensity

\section{Introduction}

The importance of the small business sector to the development of the economies of most countries in the world has become widely acknowledged (Ladzani \& van Vuuren, 2000; Rogers, 2002). Nguyen and Luu (2013) posit that SMMEs are perceived to be the backbone of any economies, given their contribution to national income. This is why, in South Africa, small businesses have been identified by government as a priority sector (Fatoki, 2012). In South Africa, the obstacles of the past, the slow growth of employment and the restructuring of the economy lend further impetus to the development and sustenance of a virile small business sector (Department of Trade \& Industry, 1998). This, according to Liedholm (2002), can be attributed to the general perception of the potential contribution of small businesses to economies of nations; the result of which has made them a significant feature of the economic landscape of the world. In reality though, this much touted potential remains inert as the contribution made by the small business sector continues to fail to reflect it. For instance, while the sector employs more than half of the working population, it accounts for less than only one-third of the GDP in South Africa (Diedrichs in Nieman, Hough \& Nieuwenhuizen, 2003). The reason this kind of situation subsists, can be attributed to a number of constraints that beleaguer the sector.

Consequently, small business research in developing economies has been mainly pre-occupied with the identification of the factors that constrain the growth of the sector. Among the different constraints identified in small business research, the issue of inaccessibility to institutional finance remains pre-eminent (Eyiah, 2001; Rogerson 1995). Freel, Carter, Tagg and Mason (2012) argue that the fact that small firms encounter credit constraints is well documented in academic literature, and this constraint hampers the formation and growth of small businesses. Clearly, the issue of access to finance by small businesses has been at the front burner of management discourse (Okafor \& Onebunne, 2012). It is the view of Lucey (2010) that the recourse to external finance is necessary because funds generated internally are often insufficient. So, in order to operate optimally, small businesses are usually dependent on debt finance (Blumberg \& Letterie, 2008). Fjose, Grunfeld and Green (2010) argue that in Sub-Sahran Africa, access to finance remains the critical obstacle encountered by SMMEs. In South Africa, the situation is not different as Rogerson (2008) 
contends that much-needed debt finance is lacking and this has become a primary cause of small business failure in the country. In spite of this, the general tendency of small business research in the specific South African context continues to be that most studies take a wide-angle focus of these constraints and so research for instance, particularly focussed on the perceived tendency for loan default of small businesses which exacerbates the problem of inaccessibility to finance is lacking (Allen-Ile \& Eresia-Eke, 2007). The reality though is that traditional providers of finance, like banks, generally view small businesses as being of a highrisk nature (Nguyen \& Luu, 2013; Okafor and Onebunne, 2012). In South Africa, for instance, this perceived risk of default is central to the reluctance of formal financial institutions (such as banks) to lend to the small business sector (Department of Trade \& Industry, 1998). The current situation is problematic and this is evidenced by the fact that the measurement of the credit risk posed by small businesses has become a major concern, worldwide (Caner \& Karan, 2012).

From the banks' or lenders' viewpoint, this high-risk notion emanates from a predictive estimation of the default risk that small businesses embody in the debt-financing relationship (Kolari, Berney \& Ou, 1997; Levitsky in Eyiah, 2001; Ovadje, 2003). Such estimates often depend on historical and projected financial information which small businesses are not known to be good at using to signal their performance-ability (Keasey \& Watson, 1991; McConnel \& Pettit, 1984). This therefore makes it pertinent to explore complementary non-financial ways by which default risk may be estimated in a bid to reduce the problem of inaccessibility to finance. Blackburn, Hart and Wainwright (2013) contend that a consideration of organisational and owner-manager characteristics are important to the overall understanding of small business performance. This opinion is corroborated by Caner and Karan (2012) who argue that non-financial factors can be significant determinants of the credit risk of a small business and so should be utilised by lenders for assessing the credit worthiness of small businesses.

Central to the notion of risk associated with the sector is the over-bearing influence that the owner-manager has over the small business, given that the small business is seen as a lengthened shadow of its owner (Owualah, 1999). In the light of this, certain characteristics of the owner-manager may therefore be critical to the prediction of the performance of the businesses. By extension, the degree of performance of a small business enterprise that has obtained a loan, is likely to impact upon the firm's tendency to meet its loan repayment obligations as at when due. Along this line of argument therefore, the thesis of this study is that some owner-manager characteristics, by their contributory role in organisational performance, would display some association with a small business' loan default propensity. This empirical study is driven by the intention:

- To investigate the nature of association, if any, that exists between identified owner-manager characteristics and loan default propensity.

- To determine if any identified associations between owner-manager characteristics and loan default propensity are business-size specific

- To relate the business' loan default propensity category to records of actual loan default incident(s). It is expected that the findings of the study would have practical implications for parties in the debt-financing equation of small businesses. This is because, if any associations are identified, they should complement existing methods of estimating small business loan default propensity and improve the ability of the bank (or lender) to separate the borrower with a high potential for default from one which would meet his/her loan obligations.

\section{Literature Review}

The Role of the Owner-Manager: Different as the causes of default may be among small businesses, the central role of the owner-manager who often requests, obtains and controls the loaned funds is critical. The success or failure of small businesses is in most cases, down to the owner-manager. Against this background, certain characteristics of the owner-manager which may aid the performance of small businesses should become key considerations in the lenders' effort to estimate the loan default propensity of a borrower. This is in tandem with Altman's (1983) argument that in the process of deciding to lend, indicators of business success can and often do serve as veritable proxies for the ability to repay the loan. It is this argument that provides the major thrust of this study and influences the theoretical framework. The paucity of literature specific to small business loan default is therefore circumvented by relying on studies that have investigated 
business performance. The expected tendency is that a lender would opt to lend to a potential business success rather than to one that does not embody traits of performance. Why? One answer could be that while success improves the ability of an organisation to meet its obligations to the lender, business failure inhibits it.

The central and influential role that the owner-manager plays in the success or performance of the firm has been established (Roper, 1999). Herron and Robinson (1993) opine that the owner-manager is the major determinant of the performance of a firm. On a similar note, Hambrick and Mason (1984) suggest with their "upper echelons" theory that organizational outcomes are dependent upon managerial characteristics of top management, which in the case of most small businesses is essentially the owner-manager. Blackburn et al (2013) as well as Hansen and Hamilton (2011) suggest that literature frequently identifies owner-managers as the most important resource within a firm. Common to these viewpoints therefore is the fact that the performance of small businesses or their organisational outcomes are largely attributable to the ownermanager. From a loan perspective therefore, it would seem that owner-manager characteristics should be important considerations given that they have a relationship with an organisation's access to credit (Nguyen \& Luu, 2013) and possible business success.

Owner-Manager Characteristics: Hambrick and Mason (1984) highlight the fact that in most firms, the chief executive reserves the highest degree of power. This, in the case of the small business, would mean that the owner is central to patterns that manifest in the enterprise. While D'Amboise and Muldowney (1988) contend that the importance of the owner in understanding the small business cannot be overemphasised, certain owner-manager characteristics may be key to the determination of small business prosperity, since Owualah, (1999) argues that the small business mirrors the potential of its owner-manager. In a bid to further explain the relationship between business managers and business performance, Hambrick and Mason (1984) proposed the upper echelons theory which holds that organisational outcomes are partially predicated upon the characteristics of members of top management. Given that some have argued that venture success is more dependent on the owner-manager than upon any other factor (Sandberg, 1986), it is imperative to identify characteristics of owner-managers, which can be relied upon to predict business performance (Sandberg, 1986; Brockhaus, 1980) as a basis for estimating loan default propensity. According to Gartner and Frid (2012), the characteristics of an owner-manager can indeed affect access to finance. Cooper, Gimeno-Gascon and Woo (1994) contend that general human capital as represented by characteristics such as education and gender, among others can impact upon business performance so much so that they can serve as indicators of high-risk or high-potential businesses. Unfortunately, findings from prior studies on the relationship between owner-manager personal characteristics and firm financing have been conflicting.

Age: One characteristic of the owner-manager of a small business that may impact upon organisational outcomes is the age of the owner-manager. Hambrick and Mason (1984) are of the opinion that the variable of age as a predictor of organisational performance has not been the subject of many studies. It is however plausible that this variable can influence other organisational characteristics and by so doing, contribute to the performance or non-performance of an organisation. The existence of some form of association between the age of the owner-manager and the firm performance has been established (Freel et al, 2012) and according to Hambrick and Mason (1984) results of these studies demonstrate strikingly consistent results. Most of these studies found that managerial youth tends to be associated with better business performance. Hambrick and Mason (1984), posit that the association of old age with lower levels of business performance and growth may be attributable to three things:

- A lower level of physical energy and mental stamina among older managers.

- A conscious or unconscious psychological commitment to maintaining the status quo.

- A high desire for financial and career security which is collateral with a lower propensity for risks that may inhibit business performance.

Along similar lines, the age of the entrepreneur has also been shown to have a negative correlation with venture ambition (Vos, Yeh, Carter and Tang, 2007) and consequently business performance. This view is shared by Nakano and Nguyen (2011) who posit that older owner-managers are more risk-averse and less 
energetic and this could adversely affect business performance. On the contrary, Freel et al (2012) contend that the age of the owner-manager could be related with human capital. This position implies that older owner-managers would be deemed to have a higher propensity for performance than younger managers. In effect, age could equip the owner-manager of the SMME with requisite experience to overcome obstacles that could lead to poor performance. Against this background, it is evident that there are discordant opinions among scholars as it pertains to the relationship between owner-manager of age and business performance. Nevertheless, the observation of Hambrick and Mason (1984) that old age has been found to be generally associated with more conservative behaviour which exerts a negative impact on the performance of the firm in addition to findings of other studies which have established that the age of an owner-manager negatively impact upon organisational growth (Nakano \& Nguyen, 2011; Delmar, 1997; Dunkelberg \& Cooper, 1982), inspire the hypothesis that:

The age of the small business' owner-managers is negatively correlated with loan default propensity.

Gender: There is hardly any consensus in literature as to how gender may relate to organisational outcomes in a small business. Cooper, Gascon and Woo (1994) observe that prior findings that pertain to gender influence on organisational success are mixed. Indeed, prior to the mid-eighties, gender was not recognised as a variable that could significantly influence the performance of an organisation (Berg, 1997). However, the emergence of a substantial number of female small business owner-managers has necessitated greater research interest in the role of gender within business organisations. This has prompted a considerable increase in research that recognises that gender differences exist (Alvarez \& Meyer, 1998). Kalleberg and Leicht (1991) contend that the relevance of gender to the performance of the small business enterprise is an important issue in research on organisational survival and success. Some studies point to the existence of stereotypical gender differences between males and females even though only scant empirical evidence that demonstrates the impact that gender may have on organisational performance exists (Lerner \& Almor, 2002; Brush \& Hisrich, 2000). Research findings indicate, for instance, that female owner-managers seemed to possess higher internal locus of control (Kalleberg \& Leicht, 1991), lower industry-specific work experience (Belcourt, Burke \& Lee-Gosselin, 1991), and lower management experience (Srinivason, Woo \& Cooper, 1994) even though the difference along this axis is thought to be diminishing (Breen, Calvert \& Oliver, 1995). With respect to management style, women are thought to be less formal (Cuba, DeCenzo \& Anish, 1983), more participative (Neider, 1987) in their approach to decision-making and more people-oriented (Kabacoff, 1998).

With particular reference to loans and anticipated default, in a comparative study of male and female business owners in Canada, Riding \& Swift (1990) found that more collateral was required by women to secure a line of credit than what was demanded of their male counterparts. Marlow and Patton (2005) suggest that the idea that gender may influence a lender's decision to provide credit persists in literature. This observation holds important implications for this research on propensity to default because it hints at the existence of a measure of gender-based influence on the estimation of propensity to default of a small business organisation. Despite the identification of certain gender-based differences in organisations, there seems to be no agreement as to how the gender of an owner-manager influences the success of a business enterprise. There are however, some arguments that recognise gender-induced differences in business performance. The first, proffers that organisations with female owner-managers perform better than those of their male counterparts (Clayton, 1988) while the second points to the fact that female-owned/managed small businesses under-perform when compared to those owned/managed by males (Rosa, Carter \& Hamilton, 1996) and indeed embody a higher probability of failure (European Commission, 1997). A third stream of thought dismisses the existence of any gender-induced impact on small business performance. In comparing survival and performance of firms managed by males or females, Kallberg \& Leicht (1991) concluded on an almost general absence of difference thereby suggesting that female-owned/managed businesses have a similar level of success when compared to those of males.

As it pertains to the issue of debt-finance, Orser, Riding and Manley (2006) opine that female owner-managed businesses are less likely to obtain bank finance. This suggests that the banks view female-owned businesses as embodying more risks than male-owned businesses. While Verbeul and Thurik (2001) suggest that gender has no bearing on the likelihood of obtaining a loan, Carter and Rose (1998) found that women, for some reason, tended to use less of institutional finance. With respect to this specific issue of repayment of loans 
obtained from financial institutions, Haynes and Haynes (1999) however, argue that women pose a lower risk of non-payment relative to men. It is this opinion, coupled with the apparent lack of consensus and absence of any research in South Africa that indicates the specific direction of gender-influence on small business performance that provide the platform for this study to hypothesise that:

There is a correlation between owner-manager gender and loan default propensity.

Education: It would appear that small-business literature tends to suggest that owner-manager education positively correlates with business performance (Freel et al, 2012). Cooper, Gascon and Woo (1994) contend that education may serve as a useful proxy for important qualities such as commitment, discipline, motivation, self-confidence and problem-solving ability. This is because the acquisition of formal education often requires substantial levels of the qualities mentioned and can therefore pass as a veritable indicator of a person's values and cognitive preferences (Hambrick \& Mason, 1984). In a similar vein, Blackburn et al (2013), opine that the educational levels of owner-managers demonstrate a positive association with business performance. On the strength of this opinion, it seems plausible to insinuate that those who have acquired formal education are likely to have higher levels of the qualities earlier alluded to, which inadvertently may prove useful for the management of businesses. The relationship between education and organisational outcomes may become clearer in the light of the fact that such outcomes are determined by choices or decisions taken by top management in the organisation. The influence that education may have on business performance seems related to the fact that it brings about specific mental and social development of the individual and so, is likely to enhance conceptual skills that should equip the individual with a higher capacity to cope with problems and take decisions. Hambrick and Mason (1984) contend that to some degree, educational levels attained by an individual reflect the person's knowledge and skill base.

The relationship between both variables appears so clear that Cooper and Gimeo-Gascon and Woo (1994) report that 10 out 17 earlier studies had found positive relationships between level of education and business performance. The other seven studies seemingly failed to establish the existence of a significant relationship between the explanatory variable of the owner-manager's level of education and the dependent variable of business performance. Cooper et al, (1994) further posit that no studies have reported negative relationships between both variables. Following a study of theirs, Kasseeah \& Thoplan (2012) contend that the level of education of an owner-manager contributes positively to the performance of the SMME. Their argument is that higher education equips owner-managers with a better understanding of the requirements for operating a successful business. While most research results support the existence of a positive relationship between education and business performance (Blackburn et al, 2013; Gartner \& Frid. 2012; Dunkelberg \& Cooper, 1982; Roper, 1999; van Praag \& de Wit, 2001), it is instructive to note that contrary to this position, Westhead (1995) found a negative association between both variables and concluded that higher educational levels tended to inhibit business performance. Given the preponderance of research findings in favour of the existence of an association between educational levels attained by an owner-manager and the performance of his/her business organisation, it is therefore expected that the relationship with business performance would have a ripple effect on the business' loan default propensity and so, this study hypothesises that:

Level of formal education of the owner-manager is inversely related to loan default propensity.

\section{Methodology}

In order to achieve the objectives of this study, a cross-sectional approach in which the survey method of gathering data was used. Though the study was a primary research, it was one of an applied nature because it is problem-oriented and is directed towards solving particular intellectual puzzles with practical implications. The study population comprised enterprises in the small business sector operating in the Durban area of South Africa. The population was however delimited to the formal sector only. The motivation was that those in the informal sector were unlikely to have any meaningful banking relationships, which would have qualified them for bank loans. Only registered small businesses that had bank accounts were therefore considered for the study. While it was desirable to reach all elements that met the study population criteria, it was impracticable and this made the utilisation of a sample, imperative. Moreover, the absence of a comprehensive compendium of small businesses in Durban / South Africa gave impetus to the use of a sample in this instance. 
116 of the 350 questionnaires distributed to businesses in small business sector were returned (see Table 1). This represents a response rate of about $33.1 \%$. This response rate is considered satisfactory especially as Curran and Blackburn (2001) argue that small business research is typically characterised by low response rates.

Table 1: Response to questionnaire

\begin{tabular}{lll}
\hline Questionnaires distributed & Valid questionnaires returned & Response rate \\
\hline 350 & 116 & $33.1 \%$ \\
\hline
\end{tabular}

The questionnaire contained a loan default propensity scale which had a Cronbach alpha index of 0.83 , suggesting that its component items are highly correlated with one another and the scale can be considered to be a single construct scale. Correlation analysis that sought to establish hypothesised associations between the dependent variable of propensity to default and the independent variables was undertaken. Cross tabulation of loan default propensity categories with actual loan default records was also done.

\section{Results}

The respondent group of the study comprised different organisations across the small business enterprise spectrum. The dispersion of the members of the sample is shown in Table 2.

Table 2: Current size of business organisation

\begin{tabular}{|c|c|c|c|c|c|}
\hline $\begin{array}{ll}\text { Size } & \text { of } \\
\text { Business }\end{array}$ & $\begin{array}{ll}\text { No. } & \text { of } \\
\text { Employees }\end{array}$ & Frequency & Percentage & $\begin{array}{l}\text { Cumulative } \\
\text { Frequency }\end{array}$ & $\begin{array}{l}\text { Cumulative } \\
\text { Percentage }\end{array}$ \\
\hline Very Small & $1-10$ & 29 & 25.00 & 29 & 25.00 \\
\hline Small & $11-50$ & 52 & 44.83 & 81 & 69.83 \\
\hline Medium & $51-100$ & 35 & 30.17 & 116 & 100 \\
\hline
\end{tabular}

Most of the owner-managers were between 31 and 40 years of age (see Table 3). Of the five categories of age that were created for the study, the smallest group was that of owner-managers who were under 21years of age $(4.31 \%)$ followed by those who were above 50 years $(14.66 \%)$. These figures suggest that over $80 \%$ of owner-managers of small business fall within the 21-50 age-bracket which is typical of South Africa's working population.

Table 3: Age of owner-managers

\begin{tabular}{lllll}
\hline Age Categories & Frequency & Percentage & $\begin{array}{l}\text { Cumulative } \\
\text { Frequency }\end{array}$ & $\begin{array}{l}\text { Cumulative } \\
\text { Percentage }\end{array}$ \\
\hline$<21$ years & 5 & 4.31 & 5 & 4.31 \\
21-30 years & 21 & 18.10 & 26 & 22.41 \\
31-40 years & 43 & 37.07 & 69 & 59.48 \\
41-50 years & 30 & 25.86 & 99 & 85.34 \\
$>$ 50years & 17 & 14.66 & 116 & 100.00 \\
\hline
\end{tabular}

As it relates to owner-manager gender, one of the explanatory variables of this investigation, findings suggest an unequal distribution of male and female owner-managers (see Table 4). While about two-thirds of the owner-mangers are male, only one-third is female. This indicates that in the respondent group, the ratio of female to male owner-managers is about 1:2 which suggests that males dominate the small business sector.

Table 4: Gender of owner-managers

\begin{tabular}{lllll}
\hline Gender Categories & Frequency & Percentage & $\begin{array}{l}\text { Cumulative } \\
\text { Frequency }\end{array}$ & $\begin{array}{l}\text { Cumulative } \\
\text { Percentage }\end{array}$ \\
\hline Male & 78 & 67.24 & 78 & 67.24 \\
Female & 38 & 32.76 & 116 & 100.00 \\
\hline
\end{tabular}


The highest level of education obtained by the owner-managers of the small businesses in the sample was an independent variable in the study. The need for this was based on the assumption that the educational level of the owner-manager may influence the manner in which decisions are taking in the business and consequently its propensity for loan default. The findings presented in table 5 show that while $17.24 \%$ had primary education, $46.55 \%$ of them had acquired secondary education and $31 \%$ had obtained tertiary level education. $5.17 \%$ however had no form of formal education meaning that they had neither been through primary, secondary or tertiary institutions of learning.

Table 5: Level of education of owner-managers

\begin{tabular}{|c|c|c|c|c|}
\hline $\begin{array}{ll}\text { Level } & \text { of } \\
\text { Education } & \end{array}$ & Frequency & Percentage & $\begin{array}{l}\text { Cumulative } \\
\text { Frequency }\end{array}$ & $\begin{array}{l}\text { Cumulative } \\
\text { Percentage }\end{array}$ \\
\hline None & 6 & 5.17 & 6 & 5.17 \\
\hline Primary & 20 & 17.24 & 26 & 22.41 \\
\hline Secondary & 54 & 46.55 & 80 & 68.97 \\
\hline Tertiary & 36 & 31.03 & 116 & 100.00 \\
\hline
\end{tabular}

\section{Measures of central tendency and dispersion}

Measures of central tendency attempt to locate the centre of the distribution as well as provide additional information. Scores obtained by the 116 respondents on the propensity to default sale ranged between 1.3 and 4.5. The mode and median for this scale were 2.3 and 2.9 respectively. The mean score indicates that a typical score in the data set was between 2 and 3, tending towards 3. A standard deviation of 0.709 from the mean score of 2.985 was established. The fact that for this scale, the mean is approximately the same as the median and the mode is also an indication of a symmetrical distribution.

Skewness and kurtosis were also determined for the loan default propensity scale. The measure of skewness of the graph depicting the distribution of responses on the propensity to default scale was 0.037 while the associated kurtosis measure for this scale is -0.891 . Given the fact that the measures of skewness and kurtosis are not equal to zero, it can be inferred that the distribution differs, to some extent, from a normal one. Furthermore, for the loan default propensity scale, the D statistic was 0.031 and this is indicative of nonsignificance. The Kolgomorov-Smirnov test and the normal probability plot indicate that the distribution resembles a normal one even though it is not technically normal.

\section{Cross tabulation and correlation of loan default propensity scores and actual default}

An attempt was made to determine if businesses that scored high on the propensity to default scale did actually default and vice-versa. In order to do this all the companies were categorised into two groups on the basis of the scores they obtained on the propensity to default scale. The mean score for this scale was 2.9. Those who obtained scores above 2.9 were considered to belong in the low-propensity to default category and those that obtained scores lower than 2.9 were considered to be in the high-propensity to default group.

Table 6: Cross tabulation of loan-default-propensity category with actual default

\begin{tabular}{|c|c|c|c|c|c|c|}
\hline & & & $\begin{array}{l}\text { Company has no } \\
\text { default record }\end{array}$ & $\begin{array}{l}\text { Company has } \\
\text { record of default }\end{array}$ & $\mathbf{a}$ & Totals \\
\hline High propensity & to & Freq & 14 & 45 & & 59 \\
\hline \multirow[t]{3}{*}{ default category } & & Percent & 12.07 & 38.79 & & 50.86 \\
\hline & & Row \% & 23.73 & 76.27 & & \\
\hline & & Column \% & 35.00 & 59.21 & & \\
\hline propensity & to & Freq & 26 & 31 & & 57 \\
\hline \multirow[t]{3}{*}{ default category } & & Percent & 22.41 & 26.72 & & 49.14 \\
\hline & & Row \% & 45.61 & 54.39 & & \\
\hline & & Column \% & 65.00 & 40.79 & & \\
\hline \multirow[t]{2}{*}{ Total } & & Freq & 40 & 76 & & 116 \\
\hline & & Percent & 34.48 & 65.52 & & 100 \\
\hline
\end{tabular}


Table 6 indicates that $76(66 \%)$ of the 116 businesses that constituted the relevant sample for the study had a record of actual default while $40(34 \%)$ did not. Of the entire group, $45(76 \%)$ of the 59 companies in the high propensity to default category had defaulted on their bank loans at some point in time. $24 \%$ of companies in this category however did not appear to have any record of default. There were 57 companies that were categorised as having a low propensity to default. In this category, 26 (or 46\%) of the small businesses had no record of default while 31 (or 54\%) of them had defaulted sometime in the past.

Correlation tests were undertaken to further ascertain the relevance of the loan default propensity score obtained by small business organisations by relating them to actual defaults in the form of default ratios. The default ratio was determined by dividing the number of default incidents experienced by an organisation with number of loans obtained.

Default ratio $(D R)=($ No. of loan defaults $) /($ No. of loans obtained $)$

Table 7: Correlation between loan-default-propensity scores (LDP) and default ratio (DR)

\begin{tabular}{|c|c|c|c|c|}
\hline & & & LDP & DR \\
\hline \multirow{6}{*}{$\begin{array}{l}\text { All } \\
\text { organisations }\end{array}$} & LDP & Pearson Correlation & 1.000 & 0.277 \\
\hline & & Sig. (2-tailed) & & 0.003 \\
\hline & & $\mathrm{N}$ & 116 & 116 \\
\hline & DR & Pearson Correlation & 0.277 & 1.000 \\
\hline & & Sig. (2-tailed) & 0.003 & \\
\hline & & $\mathrm{N}$ & 116 & 116 \\
\hline \multirow{6}{*}{$\begin{array}{l}\text { Medium-sized } \\
\text { organisations }\end{array}$} & LDP & Pearson Correlation & 1.000 & 0.708 \\
\hline & & Sig. (2-tailed) & & 0.001 \\
\hline & & $\mathrm{N}$ & 35 & 35 \\
\hline & DR & Pearson Correlation & 0.708 & 1.000 \\
\hline & & Sig. (2-tailed) & 0.001 & \\
\hline & & $\mathrm{N}$ & 35 & 35 \\
\hline \multirow{6}{*}{$\begin{array}{l}\text { Small-sized } \\
\text { organisations }\end{array}$} & LDP & Pearson Correlation & 1.000 & 0.409 \\
\hline & & Sig. (2-tailed) & & 0.003 \\
\hline & & $\mathrm{N}$ & 52 & 52 \\
\hline & DR & Pearson Correlation & 0.409 & 1.000 \\
\hline & & Sig. (2-tailed) & 0.003 & \\
\hline & & $\mathrm{N}$ & 52 & 52 \\
\hline \multirow{6}{*}{$\begin{array}{l}\text { Very } \\
\text { small-sized } \\
\text { organisations }\end{array}$} & LDP & Pearson Correlation & 1.000 & -0.172 \\
\hline & & Sig. (2-tailed) & & 0.371 \\
\hline & & $\mathrm{N}$ & 29 & 29 \\
\hline & DR & Pearson Correlation & -0.172 & 1.000 \\
\hline & & Sig. (2-tailed) & 0.371 & \\
\hline & & $\mathrm{N}$ & 29 & 29 \\
\hline
\end{tabular}

The results of the correlation analysis as shown in table 7 indicate that the correlation between propensity to default score and default ratio was significant in all cases except for very small-sized businesses employing between 1 and 10 persons. The strongest relationship was identified among medium-sized organisations where the Pearson correlation coefficient was 0.708 indicating a strong and positive association between the variables of interest. Among small sized organisations, this relationship also existed even though in a weaker form as the associated Pearson correlation coefficient was 0.409 .

When all the organisations were subjected to similar examination, the relationship between loan default propensity category and default ratio remained positive though quite tenuous in this case. These results underline the relevance of the propensity to default score of an organisation in trying to gauge the likelihood of default. 


\section{Test of Hypotheses}

Partial correlation analysis was undertaken to establish or disprove hypothesised relationships between individual explanatory variables and the dependent variable. In testing the relationship that exists between the selected explanatory variable and the dependent variable, all other explanatory variables were controlled for. The basis for the acceptance or rejection of each hypothesis is the significance of the 2-tailed test. Essentially, at a $5 \%$ confidence level, If $\mathrm{p}<0.05$, the null hypothesis is rejected.

\section{Hypothesis 1}

$H 1_{A}$ : The age of the small business' owner-managers is negatively correlated with loan default propensity

H10: The age of the small business' owner-managers is not correlated with loan default propensity

Table 8: Correlation matrix for owner-manager age and loan default propensity

\begin{tabular}{llll}
\hline & LDP & AG \\
\hline LDP & Correlation & 1.000 & 0.143 \\
& Significance (2-tailed) & & 0.148 \\
df & 0 & 102 \\
AG & Correlation & 0.143 & 1.000 \\
& Significance (2-tailed) & 0.148 & \\
df & 102 & 0 \\
\hline
\end{tabular}

The results obtained show that $p$-value is 0.148 ( $p>0.05)$, which implies the non-existence of a statistically significant relationship between the explanatory variable of owner-manager age and the small business' loan default propensity. This result provides the basis for the acceptance of the null hypothesis that suggests the absence of a relationship between age and loan default propensity.

Interestingly, the results obtained for the same test conducted on the sub groups of "very small" ( $\mathrm{p}=0.621$ ) and "small" ( $p=0.270)$ enterprises returned similar results indicating that the association between the variables of interest, is not statistically significant. However, the results were different for the sub-group of medium-sized enterprises where the relationship between age and loan default propensity was statistically significant given the $p$-value of 0.042 that was obtained. The correlation coefficient of 0.401 indicates that the relationship that exists is a direct but tenuous one.

\section{Hypothesis 2}

$H 2_{A}$ : There is a correlation between owner-manager gender and loan default propensity.

H20: There is no correlation between owner-manager gender and loan default propensity.

Table 9: Correlation matrix for owner-manager gender and loan default propensity

\begin{tabular}{llll}
\hline & LDP & GE \\
\hline LDP & Correlation & 1.000 & 0.016 \\
& Significance (2-tailed) & & 0.869 \\
df & 0 & 102 \\
GE & Correlation & 0.016 & 1.000 \\
& Significance (2-tailed) & 0.869 & \\
df & 102 & 0 \\
\hline
\end{tabular}

The results obtained show that the p-value is $0.869(p>0.05)$, the implication of which is that the hypothesised association of gender of the owner /manager and the small business' propensity to default on a loan, is of no statistical significance. Other p-values obtained were $0.564,0.237$ and 0.224 for the very small, small and medium-sized enterprises respectively. On the basis of these results, the null hypothesis which suggests the non-existence of a relationship between owner-manager gender and the small business' loan default propensity cannot be rejected. 


\section{Hypothesis 3}

$H 3_{A}$ : Level of formal education of the owner-manager is inversely associated with loan default propensity.

H30: Level of formal education of the owner-manager is not associated with loan default propensity.

Table 10: Correlation matrix for owner-manager level of formal education and loan default propensity

\begin{tabular}{llll}
\hline & LDP & FE \\
\hline LDP & Correlation & 1.000 & 0.120 \\
& Significance (2-tailed) & & 0.223 \\
df & 0 & 102 \\
FE & Correlation & 0.120 & 1.000 \\
& Significance (2-tailed) & 0.223 & 0 \\
\hline df & 102 & 0 \\
\hline
\end{tabular}

The correlation matrix in table 1.10 shows that the p-value obtained when the anticipated relationship between formal education of the owner-manager and the business' loan default propensity was put to test was 0.223 . This figure is higher than 0.05 and this provides a platform for the study to conclude that there is no statistically significant association between the explanatory and dependent variables of interest.

This finding of non-significance was consistent even when the same procedure was undertaken for the other sub-groups of businesses in the sample. Other p-values obtained were $0.227,0.955$ and 0.150 for the very small, small and medium-sized enterprises respectively. On this premise, the study therefore is unable to reject the null hypothesis which suggests that there is no relationship between the level of formal education of an owner-manager and loan default propensity.

\section{Discussion of Findings}

\section{- Relationship between owner-manager's age and loan default propensity}

The study hypothesised an inverse relationship between the age of the owner-manager and loan default propensity. Statistical results indicate that no significant relationship exists between these two variables for the aggregate group of responding businesses and for the component sub-groups of 'very small' and 'small' businesses too. The interpretation of this is that the age of the owner-manager of a small business bears no identifiable association with loan default propensity.

Interesting, however, for establishments in the medium-sized businesses group, the relationship between the variables of age and loan default propensity was significant. The association between both variables in this case was positive even though it was a weak. This implies that for medium-sized businesses employing between 51-100 persons, the age of the owner could serve as a probable indication of loan default propensity. This finding suggests that medium-sized businesses under the management of older people embody higher loan default propensities.

Perhaps this situation arises against the backdrop of the fact that owner-managers who are younger may be more amenable to change which may cause their businesses to be more dynamic, adaptive and responsive to environmental flux. Furthermore, the younger generation might have the ability to cultivate and maintain beneficial social networks in addition to having a better rapport with the workforce, which may be predominated by individuals in similar age brackets. All this should augur well for the medium-sized business as against a rigid and bureaucratic disposition that may be characteristic of older owner-managers. The finding, as it relates to medium-sized businesses, somewhat synchronises with results of earlier studies of Nakano and Nguyen (2011), Vos, Yeh, Carter and Tang (2007) and, Hambrick and Mason (1984) who all found that better business performance tends to bear an inverse relationship with the age of the owner-manager. This clearly draws from the fact that a risk-averse and conservative nature may not augur well for the business. This is particularly the case when the relationship between risk and return is considered. 


\section{- Relationship between owner-manager gender and loan default propensity}

The study proposed that businesses with female owner-managers would embody a higher loan default propensity relative to those with male owner-managers. The result of the test of association between this explanatory variable and loan default propensity however shows that there is no significant relationship that exists between them. These findings resonate with the works of Verbeul and Thurik (2001), Sorenson, Hawkins and Sorenson (1995), Johnson and Storey (1993) as well as Kallberg and Leicht (1991) who all found that there were really no gender-induced differences as it pertains to outcomes that attend small business operations. In the same vein, it contradicts the findings of the studies of Boden and Nucci (1999) and Clayton (1998) all of which found that gender bore some association with organisational outcomes, principally, performance. In spite of this, given the position of Orser, Riding and Manley (2006) and Carter and Rose (1998) who found that female owner-managed businesses are less likely to obtain bank finance, lenders need to pay attention to the development of products that specifically target female owner-managers. This is especially necessary given the emergence of many female entrepreneurs in the post-apartheid era in South Africa.

\section{- Relationship between Owner-manager's level of formal education and loan default propensity}

The initial thought of the study was that a possible relationship exists between the level of formal education attained by the owner-manager of a small business and the business' likelihood to default on a bank loan. Statistical results obtained, however do not show any indication of this. Results for all the categories of small businesses examined, point to the absence of a significant relationship between the explanatory variable of formal education and the dependent variable of loan default propensity.

The findings of this study fail to align with conclusions drawn by Blackburn et al (2013), Kasseeah \& Thoplan (2012) and van Praag and de Wit (2001) that formal education is associated with better organisational performance which, presumably, should result in a lower loan default propensity. The implication of this may well be that lending organisations should look beyond merely the educational qualification of the ownermanager and try to establish the extent of the relevance of an acquired qualification to the business that he/she is operating. Perhaps the factor of relevant experience could also be a critical consideration.

\section{Conclusion and Recommendations}

The result of the study points to the existence of similarities in the absence of any significant association that the independent variables of gender and education have with the dependent variable of loan default propensity across the entire spectrum of small businesses. This result therefore provides no impetus for lenders to request more collateral from women to secure a line of credit relative to their male counterparts as was highlighted by Riding \& Swift (1990).

With respect to the non-financial variable of age that the study investigated, the existence of a significant association between age and loan default propensity for medium-sized businesses is interesting. This is because for the other categories of small businesses, there was no such significant association. The implication of this is therefore that while the age of the owner-manager appears inconsequential when the staff strength is less that 50, it is an important non-financial variable for enterprises at the upper-end of the small business spectrum. The finding of the study is that medium-sized businesses owned/managed by younger persons portend lower loan default propensities. This may be because such young people are more likely to be very hardworking, ambitious, entrepreneurial and growth driven; which explains why they established their enterprises and nurtured them to the point where they employ so many people. The implication of this against the background of the knowledge that the greater percentage of the working population in South Africa is aged 25 - 44 years (Statistics South Africa, 2009) could be that age-harmony rather than age-discord between the average age of employees and that of the owner-manager could augur well for the business and its ability to repay a loan.

The finding that $66 \%$ of all businesses in the sample had defaulted on a loan at one point or another provides ample reason why banks and other lenders consider small business loans as being very risky. This result 
highlights the need for small business support organisations to do more to aid the performance of small businesses. Furthermore, it provides evidence that more attention needs to be paid to the issue of loan default propensity of small businesses. The identified positive correlations between loan default propensity and default ratio shows that small businesses who ultimately default often embody the propensity to do so. The need for tangible support in terms of purpose-fit education and training for owner-managers of small business in a bid to reduce business loan default propensities is therefore, imperative.

Future Research: The importance of research that focuses on the problem of inaccessibility to finance cannot be overemphasised. While the current study was limited to only a geographical region (Durban), it might be interesting to attempt to validate some of the findings in other regions as some of the variables considered may be subject to geographical nuances. This is because as noted by a number of scholars, the issue of inaccessibility to finance faced by small businesses is not limited to the Durban area or indeed South Africa. The search for non-financial predictors of loan default propensity would therefore remain meaningful for several countries, as it pertains to small businesses.

The non-significant nature of most of the relationships investigated opens the way for the search for other non-financial variables which may portend more significant relationships with the dependent variable of loan default propensity. The need such a study is heightened by the fact that continued dependence on financial indicators by formal lenders does not favour the small business sector.

Furthermore, it is believed that the value of a study of this nature can be enhanced if the research is a longitudinal rather than cross-sectional one. Human beings and businesses are dynamic and so it would be interesting to see if the non-financial characteristics that could be relied upon in the small business lending context would indeed lend themselves to a reduction in business loan default. The association may be established with a cross-sectional study but the true test of such a relationship may only be achieved through a longitudinal study. This is essentially because the securing of a loan and its consequent repayment takes place over a period. Such an investigation would therefore appear more suited to a longitudinal study as opposed to simply relying on a snapshot. So, it is pertinent that a similar study is conducted with a longitudinal approach and more independent non-financial variables in the mix. The unexpected and intriguing finding of an association of higher propensity to default with lower default ratios in very-small sized businesses (that employ less than 10 people) is worthy of further investigation.

\section{References}

Allen-Ile, C \& Eresia-Eke, C. (2007). The role of management style on the propensity for loan default by small businesses. Journal of business and management dynamics 1, 14-27.

Altman, E. (1983). Corporate financial distress - A complete guide to predicting, avoiding and dealing with bankruptcy. New York: John Wiley \& Sons.

Alvarez S. \& Meyer, G. (1998). Why do women become entrepreneurs? Frontiers of Entrepreneurship Research.

Bates, C. (1991). Commercial bank finance in white and black owned small business start-ups. Quarterly Review of Economics and Business, 31 (3), pp. 64-80.

Baumback, C. (1983). Small Business Management Practice, Englewood Cliffs: Prentice Hall.

Berg, N. (1997). Gender, Place and Entrepreneurship. Entrepreneurship and regional development 9, 259-268.

Belcourt, M. Burke, R. \& Lee-Gosselin, H. (1991). The glass box: Women business owners in Canada. Background paper, Canadian advisory council on the state of women. Ottawa, Ontario

Bhatt, N. and Tang, S. (1998). The Problem of Transaction Costs in Group-based Micro-lending: An Institutional Perspective. World Development, (26)4, 623-637.

Blackburn R., Hart M. \& Wainwright T. (2013). Small business performance: business, strategy and ownermanager characteristics. Journal of small business and enterprise development 20(1), 9-27

Boden R. \& Nucci A. (1999). On the survival prospects of men's and women's new business ventures. Journal of Business Venturing, 15; 347-362

Breen, J., Calvert, C. \& Oliver, J. (1995). Female entrepreneurs in Australia: An investigation of financial and family issues. Journal of Enterprising Culture 3(4), 445-461

Brockhaus, R. (1980). Risk-taking propensity of entrepreneurs. Academy of Management Journal 23(3), 509520 
Brush, C. \& Hisrich, R. (2000). Women-owned businesses: An exploratory study comparing factors affecting performance. Working paper of the research institute for small and emerging businesses inc. www.riseb.org

Caner, S. \& Karan, M (2012). Screening creditworthiness of SMEs: The case of small business assistance in Turkey. Multinational finance journal, 16 (1), 1-20

Carlsson, G. \& Karlsson, K. (1970). Age, Cohorts and the generation of generations. American sociological review $35,710-718$

Carter, S. \& Rose, P. (1998). The financing of male- and female-owned businesses. Entrepreneurship and regional development, 10(3), 225-241.

Child, J. (1974). Managerial and organisational factors associated with company performance. Journal of Management studies 11, 13-27

Clayton, K. (1998). Women's work: Success in small business. Australian CPA; Melbourne Nov: 36-39

Coleman, S. (2000). Access to Capital and Terms of Credit: A Comparison of Men-and Women-Owned Small Businesses. Journal of Small Business Management, 3(38), 37-52.

Cooper A., Gimeno-Gascon F. \& Woo C. (1994). Initial human and financial capital as predictors of new venture performance. Journal of Business Venturing 9, 371-395.

Cuba, R., DeCenzo, D., and Anish, A. (1983). Management practices of successful female business owners. American Journal of small business 8(2), 40-45.

Curran, J. and Blackburn, R. (2001). Researching the small enterprise. London: Sage publications.

D'Ambroise, G. \& Muldowney, M. (1988). Management theory for small business: attempts and requirements. Academy of management review 13, 226-240.

Delmar F. (1997). Measuring Growth: Methodological considerations and empirical results in Donckels R. and Miettinen A. (Eds), Entrepreneurship and SME Research on its way to the next millennium, Aldershot, Ashgate.

Department of Trade and Industry (1998). Financial Access for SMMEs: Towards a comprehensive strategy. Paper prepared by the Centre for Small Business Promotion, Department of Trade and Industry (DTI) for the South African Parliament (April).

Dunkelberg W. and Cooper A. (1982). Patterns of Small Business Growth. Academy of Management Proceedings, 409-413

Eyiah, A. (2001). An Integrated Approach to Financing Small Contractors in Developing Countries: A Conceptual Model. Journal of Construction Management and Economics, 19, 511-518.

European Commission (1997). Women as agents of regional development. Official publications service of the European community, Luxemburg.

Fatoki, 0. (2012). The impact of entrepreneurial orientation on access to debt finance and performance of small and medium business in South Africa. Journal of social sciences 32(2), 121-131.

Fjose, S., Grunfeld, L. \& Green, C. (2010). SMEs and growth in Sub-Saharan Africa. MENON Business Economics

Freel M., Carter S., Tagg S. \& Mason, C. (2012). The latent demand for bank debt: characterizing discouraged borrowers. Small business economics 38, 399-418

Hambrick, D. and Mason, P. (1984). Upper Echelons: The organisation as a reflection of its top managers. Academy of Management Review, 9(2), 193-206.

Hansen B. \& Hamilton R. (2011). Factors distinguishing small firm growers and non-growers. International small business journal 29(3), 278-291.

Hart, P. \& Mellons, J. (1970). Management youth and company growth: A correlation? Management Decision $4(2), 50-53$

Haynes G. \& Haynes D. (1999). The debt structure of small businesses owned by women in 1987 and 1993. Journal of Small business Management 37(2), 1-20.

Hempell, G. and Sinonson, D. (1990). Bank Management. New York: John Wiley \& Sons Inc.

Herron, L. and Robinson, R. (1993). A structural model of the effects of entrepreneurial characteristics on venture performance. Journal of Business Venturing, 8, 281-294.

Gartner, W. \& Frid, C. (2012). Financing the emerging firm. Small business economics, 39, 745-761.

Johnson S. \& Storey D. (1993). Male and Female Entrepreneurs and their business: A comparative study in Allen s. and Truman C. (Eds), Women in Business: Perspectives on Women Entrepreneurs. London, Routledge Press, 70-83

Kabacoff, R. (1998). Gender differences in organisational leadership: A large sample study. Paper presented at the meeting of the American psychological association. San Francisco, CA 
Kalleberg, A. and Leicht, K. (1991). Gender and Organizational Performance: Determinants of Small Business Survival and Success. Academy of Management Journal, 34(1), 136-161.

Kasseeah, H., \& Thoplan, R. (2012). Access to financing in a small island economy: Evidence from Mauritius. Journal of African business, 13(3), 221-231.

Keasey, K. and Watson, R. (1991). The state of the art of small firm failure prediction: Achievements and Prognosis. International Small Business Journal, 9(4), 11-29.

Kolari, J., Berney, R. and Ou, C. (1997). Study Finds Small Banks Profit from Small Business Lending, Despite Risks. Journal of Retail Banking, 3(19), 17-24.

Kotey, B. (1999). Debt Financing and Factors Internal to the Business. International Small Business Journal, 17(3), 11-29.

Ladzani, W. and Van Vuuren, J. (2002). Entrepreneurship Training for Emerging SMEs in South Africa. Journal of Small Business Management, 40(2), 154-161.

Lerner M. \& Almor T. (2002). Relationships among strategic capabilities and the performance of womenowned small ventures. Journal of Small Business management, 40(2), 109-125.

Liedholm, C. (2002). Small firm dynamics: Evidence from Africa and Latin America. Journal of Small Business Economics, 18, 227-242.

Lucey, B. (2010). Determinants of capital structure of Irish SMEs. Small business economics, 35(3), 1-25.

Lussier, R. (1995). A non-financial business success versus failure prediction model for young firms. Journal of Small Business Management, 33(1), 8-20.

Lussier, R. and Pfeifer, S. (2001). A cross-national prediction model for business success. Journal of Small Business Management, 39(3), 228-239.

Marlow, S. \& Patton, D. (2005). All credit to men? Entrepreneurship, finance and gender. Entrepreneurship Theory and Practice, (29), 717-736.

McConnel, J. and Pettit, R. (1984). Application of the modern theory of finance to small business firms. Small Business Finance, 42, 97-126.

Mead, D. and Liedholm, C. (1998). The Dynamics of Micro and Small Enterprises in Developing Countries. World Development, 26(1), 61-74.

Neider, B. (1987). A preliminary investigation of female entrepreneurs in Florida. Journal of small business management 25(3), 22-29.

Nguyen, N. \& Luu, N (2013). Determinants of financing pattern and access to formal/informal credit: The case of small and medium-sized enterprises in Vietnam. Journal of management research, 5(2), 240-259.

Okafor, R. \& Onebunne, I. (2012). Review of financial challenges of Nigerian entrepreneurs in an attempt to reduce financial institutions' risk perception index of small firms: Evidence from survey data. Developing country studies, 2(11), 197-204.

Orser, B., Riding A., \& Manley, K. (2006). Women entrepreneurs and financial capital. Entrepreneurship Theory and Practice (30), 643-665.

Ovadje, F. (2003). Access to Credit: A study of the Perception of Nigerian Women Entrepreneurs. Lagos Business School Management Review, 8(1), 21-27.

Owualah, S. (1999). Entrepreneurship in Small Business Firms. Lagos: G-Mag Educational Publishers.

Riding, A. \& Swift, C. (1990). Women business owners and terms of credit: some empirical findings of the Canadian experience. Journal of business venturing, 5(5), 327-340.

Rogers, B. (2002). Funding of SMEs: Sourcing for funds and problems limiting access. The official journal of the Institute of chartered accountants of Nigeria, 35(1), 15-18.

Rogerson, C. (1995). SMME Infrastructure and policy in South Africa. International Small Business Journal, $13(3)$.

Rogerson, C. (2008). Tracking SMME development in South Africa: Issues of finance, training and regulatory environment. Urban forum, 19(1), 61-81.

Roper, S. (1999). Modelling small business growth and profitability. Small Business Economics, 13, 235-252.

Rosa, P., Carter, S. \& Hamilton, D. (1996). Gender as a determinant of small business performance: Insights of a British study. Small Business Economics 8, 463-478.

Sandberg W. (1986). New venture performance: the role of strategy and industry structure, Lexington, D.C. Heath \& Co.

Sorenson, P., Hawkins, K. \& Sorenson, R. (1995). Gender, psychological type and conflict style preference. Management communication quarterly 9(1), 115-126. 
Srivanson, R., Woo, C. \& Cooper, A. (1994). Performance determinants for male and female entrepreneurs. In Frontiers of entrepreneurship research (Ed) Bygrave, W., Birley, S., Churchill, N., Gatewood, E., Hoy, F., Keely, R., Wetzel, W. Wellesley, Mass: Babson college, 43-55.

Statistics South Africa (2009). Quarterly Labour Force Survey, Quarter 3. p.17 http://www.statssa.gov.za/publications/P0211/P02113rdQuarter2009.pdf. Accessed 01 Dec 2009.

Van Praag M. \& de Wit G. (2001). The value of investments in human and social capital for small business founders. Frontiers of Entrepreneurship research, 213-223.

Verheul, I. \& Thurik, R. (2001). Start-up capital: Does gender matter? Small business economics, 16(4), 329345.

Westhead P. (1995). Survival and employment growth: Contrasts between types of owner-managed high technology firms. Entrepreneurship and Practice, Fall, 5-27. 